\title{
FAKTOR-FAKTOR YANG BERHUBUNGAN DENGAN KEJADIAN PRE-EKLAMPSIA PADA PEREMPUAN BERSALIN
}

\author{
$\underline{\text { Mareza Yolanda Umar }{ }^{1} \text {, Psiari Kusuma Wardani }}{ }^{2}$ \\ Akademi Medica Bakti Nusantara ${ }^{12}$ \\ Email:marezaumar@gmail.com ${ }^{1,}$ psiarikusumawardani@gmail.com²
}

\begin{abstract}
ABSTRAK
Pre-eklampsia/eklampsia merupakan salah satu penyebab utama kematian ibu di dunia khususnya di negara berkembang. Tujuan penelitian ini adalah untuk mengetahui faktor-faktor yang berhubungan dengan kejadian pre-eklampsia. Jenis penelitian ini adalah penelitian kuantitatif dengan pendekatan case control dengan menggunakan data perempuan yang sedang bersalin. Teknik pengambilan sampel secara purposive sampling dengan perbandingan 1:1 dimana jumlah sampel kasus 98, sampel kontrol 98. Analisis bivariat menggunakan uji chi square sedangkan analisis multivariat menggunakan uji regresi logistik ganda. Hasil penelitian menunjukkan variabel yang berhubungan dengan kejadian pre-eklampsia adalah usia $\rho=0,004(O R=2,391)$, paritas $\rho=0,000(O R=3,100)$, riwayat hipertensi $\rho=0,000 \quad(O R=4,593)$, riwayat pre-eklampsia $\rho=0,000$ $(O R=6,290)$. Analisis mutivariat menunjukkan bahwa ibu hamil dengan riwayat pre-eklampsia memiliki peluang sebesar 8,258 kali lebih besar untuk mengalami pre-eklampsia dibandingkan dengan ibu yang tidak memiliki riwayat pre-eklampsia. Saran dalam penelitian ini adalah dapat segera mendiagnosis dini penyakit preeklampsia dan memperkecil resiko terjadinya pre-eklampsia berat. Ibu hamil hendaknya melakukan memeriksakan kehamilan secara rutin harus dilakukan agar pre-eklampsia dapat terdeteksi cepat untuk meminimalisir kemungkinan komplikasi yang lebih fatal.
\end{abstract}

Kata Kunci: Pre-eklampsia, Perempuan, Persalinan

\section{FACTORS ASSOCIATED WITH THE PRE-ECLAMPSIA EVENTS ON WOMEN IN LABOR}

\begin{abstract}
Pre-eclampsia / eclampsia is a major cause of maternal mortality in the world, especially in developing countries. The purpose of this research was to determine the factors associated with the pre-eclampsia events. The design of this research uses case control study which is using data from women in labor. Sampling technique by purposive sampling with a ratio of 1: 1 where the number of sample cases 98, control sample 98. Bivariate analysis using chi square while multivariate analysis using multiple logistic regression. . The results showed the variables related with pre-eclampsia events are age $\rho=0.004(O R=2.391)$, parity $\rho=0.000(O R=$ 3.100), history of hypertension $\rho=0.000(O R=4.593)$, history of pre-eclampsia $\rho=0.000(O R=6.290)$. Multivariate analysis showed pregnant women with history of pre-eclampsia have the opportunity of 8,258 times greater to experience pre-eclampsia compared with women who did not have a history of pre-eclampsia. Suggestions in this research is able to immediately diagnose the disease early pre-eclampsia and minimize the risk of pre-eclampsia. Pregnant mothers should conduct routine antenatal so that pre-eclampsia can be detected quickly to minimize the possibility of fatal complications
\end{abstract}

Key words: Pre-eclampsia, Women, Labor

How to Cite: Umar, M. Y., Wardani, P. K. (2017). Faktor-Faktor yang Berhubungan dengan Kejadian PreEklampsia pada Perempuan Bersalin. Aisyah: Jurnal Ilmu Kesehatan. 2 (1), 45 - 50. 


\section{Aisyah: Jurnal Ilmu Kesehatan 2 (1) 2017, - 46}

Mareza Yolanda Umar, Psiari KusumaWardani

\section{PENDAHULUAN}

Menurut data Survey Demografi Kesehatan Indonesia (SDKI) tahun 2012 Analisis angka kematian maternal menunjukkan kenaikan dari SDKI 1997 sampai dengan SDKI 2012. Rasio kematian maternal pada tahun 1997 adalah 390 kematian per 100.000 kelahiran hidup. Rasio kematian maternal menurun menjadi 307 kematian per 100.000 kelahiran hidup pada SDKI 2002-2003 dan 228 kematian per 100.000 kelahiran hidup pada SDKI 2007. Namun, angka ini meningkat pada SDKI 2012 menjadi 359 kematian per 100.000 kelahiran hidup.

Adapun yang menjadi penyebab kematian ibu di Kota Bandar Lampung tahun 2013 adalah hipertensi dalam kehamilan (6 kasus), perdarahan (4 kasus), infeksi (2 kasus), dan karena penyebab lain (7 kasus) Sedangkan jumlah kasus pre-eklampsia dan eklampsia sebesar 291 kasus dari $3.687 \mathrm{ibu}$ hamil (Dinkes Kota Bandar Lampung, 2013).

Kejadian pre-eklampsia dan eklampsia bervariasi disetiap Negara bahkan pada setiap daerah (Manuaba, 2012). Preeklampsia merupakan salah satu penyebab kematian pada ibu disarmping infeksi dan perdarahan. Faktor-faktor yang menunjang terjadinya pre-eklamsia dan eklampsia. antara lain usia, paritas, mengandung lebih dari satu orang bayi, riwayat pre-eklampsia, riwayat hipertensi (Rukiyah, 2014).

Pre-eklampsia adalah kondisi khusus dalam kehamilan ditandai dengan peningkatan tekanan darah dan proteinuria. Bisa berhubungan dengan kejang dan gagal organ ganda pada ibu (Chapman, 2006). Menurut Rukiyah (2014) beberapa penelitian yang dapat menunjang terjadinya pre-eklampsia dan eklampsia. Faktor-faktor tersebut antara lain gizi buruk, kegemukan dan gangguan aliran darah ke rahim. Faktor risiko terjadinya pre-eklampsia umumnya teradi pada kehamilan yang pertama kali, kehamilan di usia remaja dan kehamilan pada wanita diatas 40 tahun. Faktor risiko lain adalah riwayat tekanan darah tinggi yang kronis sebelum kehamilan, riwayat pre-eklampsia pada ibu atau sodara perempuan, kegemukan, mengandung lebih dari satu orang bayi, riwayat kencing manis, kelainan ginjal, lupus atau rematoid arthritis

Berdasarkan studi pendahuluan yang dilakukan di RSUD A.Dadi Tjokrodipo Bandar Lampung pada tahun 2014 terjadi peningkatan menjadi 11,4\% (184 kasus) pre-eklampsia dari $1511 \mathrm{ibu}$ bersalin.

\section{METODE}

Jenis penelitian ini adalah penelitian kuantitatif dengan pendekatan kasus kontrol. Pengumpulan data dilakukan dengan dengan menggunakan observasi data melalui rekam medis. Variabel independen penelitian ini adalah usia, paritas, riwayat pre-eklampsia, dan riwayat hipertensi, sedangkan variabel dependen yang diteliti adalah kejadian pre-eklampsia pada ibu hamil. Populasi dalam penelitian ini adalah semua ibu hamil di RSUD A. Dadi Tjokrodipo Bandar Lampung. Cara pengambilan sampel menggunakan purposive sampling. Perbandingan sampel menggunakan sampel minimal untuk studi kasus kontrol dengan perbandingan 1:1 dimana jumlah sampel kasus 98, sampel kontrol 98.

\section{HASIL DAN PEMBAHASAN}

Gambaran distribusi kasus dan control (tabel.1) dapat dilihat bahwa umur $<20$ dan $>35$ tahun, paritas, ada riwayat hipertensi, ada riwayat preeklampsia. 
Aisyah: Jurnal Ilmu Kesehatan 2 (1) 2017, - 47

Mareza Yolanda Umar, Psiari KusumaWardani

Tabel 1

Distribusi kasus dan control berdasarkan karakteristik Ibu

\begin{tabular}{llllll}
\hline \multirow{2}{*}{ Karakteristik Ibu } & \multicolumn{1}{c}{ Kategori } & \multicolumn{2}{c}{ Kasus } & \multicolumn{2}{c}{ Kontrol } \\
\cline { 3 - 6 } & & $\mathbf{N}$ & $\mathbf{\%}$ & $\mathbf{N}$ & $\mathbf{\%}$ \\
\hline \multirow{2}{*}{ Umur } & Berisiko (<20 tahun - $>35$ tahun) & 58 & 59,2 & 37 & 37,8 \\
\cline { 2 - 6 } & Tidak berisiko (20-35 tahun) & 40 & 40,8 & 61 & 62,2 \\
\hline \multirow{2}{*}{ Paritas } & Berisiko (1 anak dan $>3$ anak) & 62 & 63,3 & 35 & 35,7 \\
\cline { 2 - 6 } & Tidak Berisiko (2-3 anak) & 36 & 36,7 & 63 & 64,3 \\
\hline \multirow{2}{*}{ Riwayat Hipertensi } & Ada Riwayat Hipertensi & 53 & 54,1 & 20 & 20,4 \\
\cline { 2 - 6 } & Tidak ada Riwayat Hipertensi & 45 & 45,9 & 78 & 79,6 \\
\hline \multirow{2}{*}{ Riwayat Pre-eklampsia } & Ada Riwayat Pre-eklampsia & 54 & 55,1 & 16 & 16,3 \\
\cline { 2 - 6 } & Tidak Ada Riwayat Pre-eklampsia & 44 & 44,9 & 82 & 83,7 \\
\hline
\end{tabular}

Analisis bivariat bertujuan untuk mengetahui hubungan atau pengaruh antara satu variabel independent (bebas) dengan variabel dependent (terikat) tanpa mempertimbangkan variabel independen atau variabel risiko lainnya. Untuk mengetahui hubungan tersebut semua variabel independent satu persatu akan dilakukan uji statistik dengan kejadian preeklampsia.

Tabel 2

Hasil analisis Bivariat

\begin{tabular}{|c|c|}
\hline Variabel & $\rho$ value \\
\hline Umur & 0,004 \\
\hline Paritas & 0,000 \\
\hline Riwayat Hipertensi & 0,000 \\
\hline Riwayat Pre-eklampsia & 0,000 \\
\hline
\end{tabular}

Tabel 3

Hasil Analisis Multivariat

\begin{tabular}{|l|l|c|c|}
\hline \multicolumn{1}{|c|}{ Variabel } & $\boldsymbol{\rho}$ value & \multicolumn{1}{c|}{ OR } & 95\% CI \\
\hline Umur & 0,015 & 2,540 & $1,199-5,381$ \\
\hline Paritas & 0,003 & 3,147 & $1,467-6,748$ \\
\hline $\begin{array}{l}\text { Riwayat } \\
\text { Hipertensi }\end{array}$ & 0,000 & 6,119 & $2,703-13,849$ \\
\hline $\begin{array}{l}\text { Riwayat Pre- } \\
\text { eklampsia }\end{array}$ & 0,000 & 8,162 & $3,408-19,550$ \\
\hline
\end{tabular}

Tabel 4

Model Akhir Analisis Multivariat

\begin{tabular}{|l|l|c|c|}
\hline \multicolumn{1}{|c|}{ Variabel } & $\boldsymbol{\rho}$ value & \multicolumn{1}{c|}{ OR } & $\mathbf{( 9 5 \%} \boldsymbol{C I})$ \\
\hline Umur & 0,014 & 2,548 & $1,204-5,391$ \\
\hline Paritas & 0,003 & 3,174 & $1,489-6,765$ \\
\hline $\begin{array}{l}\text { Riwayat } \\
\text { Hipertensi }\end{array}$ & 0,000 & 6,146 & $2,719-13,893$ \\
\hline $\begin{array}{l}\text { Riwayat Pre- } \\
\text { eklampsia }\end{array}$ & 0,000 & 8,258 & $3,478-19,608$ \\
\hline
\end{tabular}

Menurut Fadlun, pada tahun 2012 menjelaskan bahwa pre-eklampsia adalah peningkatan tekanan darah yang baru timbul setelah kehamilan mencapai 20 minggu, disertai dengan penambahan berat badan ibu yang cepat akibat tubuh membengkak dan pada pemeriksaan laboratorium dijumpai protein didalam urine.

Menurut Rukiyah (2014) pre-eklampsia didasarkan pada teori yang dihubunghubungkan dengan kejadian. Itulah sebabnya pre-eklampsia disebut juga disease of theory atau gangguan kesehatan yang berasumsi pada teori. Menurut Rukiyah (2014) Beberapa penelitian yang dapat menunjang terjadinya pre-eklampsia dan eklampsia. Faktor-faktor trsebut antara lain gizi buruk, kegemukan dan gangguan aliran darah ke rahim. Faktor risiko terjadinya pre-eklampsia umumnya teradi pada kehamilan yang pertama kali, kehamilan di usia remaja dan kehamilan pada wanita diatas 40 tahun. Faktor risiko lain adalah riwayat tekanan darah tinggi yang kronis sebelum kehamilan, riwayat pre-eklampsia pada ibu atau saudara perempuan, kegemukan, mengandung lebih dari satu orang bayi, riwayat kencing manis, kelainan ginjal, lupus atau rematoid arthritis.

Faktor riwayat pre-eklampsia menurut Varney (2006) salah satu penyebab preeklampsia adalah predisposisi genetik, atas dasar tersebut riwayat pre-eklampsia pada keluarga dan individu merupakan faktor 


\section{Aisyah: Jurnal Ilmu Kesehatan 2 (1) $2017,-48$}

Mareza Yolanda Umar, Psiari KusumaWardani

risiko untuk terjadnya pre-eklampsia pada kehamilan selanjutnya. Hasil penelitian ini juga sejalan dengan penelitian yang dilakukan oleh Rozikhan (2007) mendapatkan nilai $\rho$ value $=0,001$ dan nilai $\mathrm{OR}=15,506$ dengan tingkat kepercayaan 95\% CI sebesar 5,782 - 41,562 yang berarti bahwa ibu yang mempunyai riwayat preeklampsia berpeluang untuk terjadinya preeklampsia sebesar 15,506 kali lebih besar.

Faktor riwayat hipertensi menurut Cunningham (2013) Pada sebagian wanita dengan riwayat hipertensi kronis, hipertensi dapt memburuk, terutama pada kehamilan berikutnya. Hipertensi yang diperberat oleh kehamilan seperti itu dapat disertai dengan proteinuria atau edema patologis dan kemudian disebut superimposed preeclampsia. Kerapkali superimposed preeclampsia timbul lebih awal dalam kehamilan bila dibandingkan dengan preeklampsia murni dan cenderung jadi berat pada kebanyakan kasus. Penelitian yang dilakukan oleh Rosmadewi (2010) yang dalam penelitiannya didapatkan bahwa nilai $\rho$ value sebesar 0,001 dan OR sebesar 9,116 yang berarti bahwa ibu bersalin yang memiliki riwayat hipertensi memiliki peluang untuk terjadinya pre-eklampsia sebesar 9,116 kali lebih besar dibandingkan dengan ibu yang tidak memiliki riwayat hipertensi.

\section{KESIMPULAN DAN SARAN}

Ada hubungan umur, paritas, riwayat hipertensi, riwayat pre-eklampsia, Faktor yang dominan dalam kejadian preeklampsia adalah riwayat pre-eklampsia $\rho$ value $=0,000$ dan mempunyai ibu bersalin yang memiliki riwayat pre-eklampsia berpeluang mengalami pre-eklampsia 8,258 kali lebih besar bila dibandingkan dengan ibu bersalin yang tidak memiliki riwayat pre-eklampsia

Ibu hamil hendaknya melakukan memeriksakan kehamilan secara rutin harus dilakukan di puskesmas berbasis PONED atau dibidan-bidan yang telah dilatih oleh puskesmas berbasis PONED agar preeklampsia dapat terdeteksi cepat untuk meminimalisir kemungkinan komplikasi yang lebih fatal. Akan sangat membantu jika ibu dan anggota keluarganya dilibatkan dalam mengamati gejala yang berhubungan dengan pre-eklampsia.

Hasil penelitian ini dapat menjadi bahan pertimbangan dan masukan bagi peneliti lain untuk melanjutkan penelitian tentang variabel yang belum diteliti 


\section{DAFTAR PUSTAKA}

Survey Demografi Kesehatan Indonesia (SDKI). (2012). (http://download.portalgaruda.org/arti cle.php) Diakses Tanggal 30 Agustus 2015.

Champman, Vicky. (2006). Asuhan Kebidanan Persalinan Dan Kelahiran, Alih Bahasa: Y. Kuncara, Jakarta: ECG.

Cuningham, F Gary, Et Al. (2006). Obstetri William, Alih Bahasa: Andry Hartono, Joko Suyono, Brahm U. Pendit, Jakarta, ECG.

Dinas Kesehatan Kota Bandar Lampung. (2013). Profil Kesehatan Kota Bandar Lampung.

Fadlun. (2012). Asuhan Kebidanan Patologis, Jakarta, Salemba Medika.

Manuaba, Ida Bagus Gde. (2012). Ilmu Kebidanan, Penyakit Kandungan Dan Keluarga Berencana, Jakarta, ECG.

Rosmadewi. (2010). Faktor Risiko Yang Mempengaruhi Kejadian PreEklampsia Pada Ibu Hamil Di Wilayah Puskesmas Kota Bandar Lampung Tahun 2009.

Rukiyah, Ai Yeyeh. (2014). Asuhan Kebidanan 4 Patologi Kebidanan. Jakarta: KDT.

Rozikhan. (2007). Faktor-Faktor Terjadinya Pre-Eklampsia Berat Di Rumah Sakit DR. H.Soewondo Kendal (http://eprints.undip.ac.id/4918/1/Roz ikhan.pdf) Diakses Tanggal 20 Agustus 2015.

Varney, Hellen, Et Al. (2007). Buku Ajar Asuhan Kebidanan, Alih Bahasa: Ana Lusiana, Laily Mahmudah, Gita Trisetyawati, Wilda Eka. Jakarta: ECG. 
Aisyah: Jurnal Ilmu Kesehatan 2 (1) 2017, - 50

Mareza Yolanda Umar, Psiari KusumaWardani 